\title{
The Last Thing (Posledná vec)
}

Author: Leopold Lahola

First Published: 1968

Translations: Czech (Poslední věc, 1969); Hungarian (Véletlen ismeretség, 1970); Serbian (Poslednja stvar, 1998).

Theatre Adaptation: Slovenské národné divadlo, Bratislava (2004, Peter Pavlac's adaptation of the story Facing the Enemy), directed by L'ubomír Vajdička.

Film Adaptations: Návrat domov (Return Home, based on short story Like a Dog), feature film; screenplay Leopold Lahola and Martin Frič; film director Martin Frič, premiered 28th of January, 1949; Rozhovor s nepriatelom (Facing the Enemy), feature film; screenplay Peter Pavlac, Patrik Lančarič and Marko Igonda; film director Patrik Lančarič, premiered 8th of March, 2007.

About the Author: Leopold Lahola, whose real name was Leopold Arje Friedmann (1918-1968), was a Slovak prose writer, poet, playwright, screenwriter, director and translator of Hebrew. He belongs to the second generation of World War II among Slovak prose writers. Even though he was a talented painter, as a Jew he was not allowed to complete his studies at the Faculty of Arts in Bratislava after the establishment of the Slovak State. He went through dramatic events of military labour service in the Slovak army (see Emil F. Knieža's $\rightarrow$ The Sixth Battalion, On Guard!). He volunteered to be interned in a labour camp for Jews in Nováky to share the fate of his mother and brother. After the outbreak of the Slovak National Uprising, he participated in the resistance. When he was injured, at the end of the war he served as a war correspondent. He began as a playwright who expressively interpreted the experience of war events. He initially had success in theatre (The Four Sides of the World, 1947), and worked as a screenwriter (White Darkness, 1948; Wolves' Lairs, 1948). After the Communist coup in February 1948, he was criticised and misinterpreted. In 1949, he emigrated to Israel where he worked as a director, then eventually settling in Munich in West Germany. At the end of the 1960s he was able to implement his work projects in Czechoslovakia. He died suddenly while filming The Sweet Time of Kalimagdora (1968).

Before the war he devoted himself to writing his own poetry and translating Hebrew poetry. Abroad, he engaged in screenwriting and directing. Shortly after the war, his only prosaic book, a collection of short stories, The Last Thing, came into being but it could not be published. Lahola's prose brought a deep and expressive focus on suffering, violence, as well as the absurdity of the war and the Holocaust. The author placed both events in a historical context, placing emphasis on depicting existentially motivated violence and dehumanised images of man.

Ә Open Access. ( 2021 Zora Prušková, published by De Gruyter. (cc)BY-NC-ND This work is licensed under a Creative Commons Attribution-NonCommercial-NoDerivatives 4.0 License. https://doi.org/10.1515/9783110671056-058 
Further Important Publications: Štyri strany sveta (1949, premiered 1947, The Four Sides of the World; play); Atentát (1949, premiered 1949, Assassination; play); Škvrny na slnku (1967, Sunspots; play); Inferno (1968, Inferno; play); Ako jed škorpióna (1995, Like a Scorpion's Poison; poetry); Pät hier (2005, Five Plays, ed. D. KročanováRoberts); Posledná vec a iné (2007, The Last Thing and Others, ed. J. Paštéková, contains short proses, poetry, the play Assassination, essays, interviews, letters, comments and critical reviews).

\section{Content and Interpretation}

The set of fourteen short stories of The Last Thing was created according to the timeframe of the individual pieces of prose from 1949 to 1956. It immediately reflects Lahola's biographical experience with the internment labour camp in Nováky and the resistance. The dominant theme is the experience of the war, although it is not always present. What matters is not historical, temporal circumstances, but universal human experience, events of death and threat, staged in various ways. The narrative is intentionally expressive, often brutal and distancing. Beyond that, one can find a reference to the mechanism of Judaism's metaphysics that attempts to approach evil in its "invisible" form. "There is only one way to escape the abyss: to explore, measure, determine its depth and descend into it" (the motto of the book by Cesare Pavese; Lahola, 1994, p. 22). The prose, which can be divided into four headings, bears witness to this "descent into the abyss": 1) intimate stories, which often take place indoors; relating to death and humiliation in the liquidation camps, like Twenty-Five Lashes of a Cane (Dvadsatpät' palíc) or The Open Door (Otvorené dvere). 2) Anecdotal stories about Jewish nature, character and fatal destiny with a point - with explicit reference to the events of the pogroms and persecution of the Jewish ethnicity, see Birdsong (Vtáči spev), The Funeral of David Krakower (Pohreb Dávida Krakowera) or God's Lane (Božia ulička). 3) Short stories - depicting cruel blasphemy of situational scenes from military and guerrilla actions partisans, The Last Thing (Posledná vec), The Shot Man (Zastrelený), Salvo (Salva) or Fontentieri. 4) Short stories that have a dialogic core which thematise conversation or verbal reflection on guilt, complicity, responsibility for the death and humiliation of another person: About the Body and Soul (O tele a duši), Narration in the First Person (Rozprávanie v prvej osobe), Like a Such Dog (Ako taký pes), and Facing the Enemy (Rozhovor s nepriatelom). Thanks to the author's autobiographical experience and his proximity to Judaist metaphysics, Lahola's stories appeal to readers differently than other Slovak prose on this topic. It is possible to recall a partial similarity with Ladislav Grosman's $\rightarrow$ The Shop on Main Street. Rather, Lahola's works remind more of the Czech, Polish or Italian literature. Arnošt Lustig's $\rightarrow$ Diamonds of the Night, Bruno Schulz, Paul Celan, Jean Améry, Zofia Nałkowska's $\rightarrow$ Medallions, Primo Levi, Jerzy Kosinski's The Painted Bird, Tadeusz Borowski's $\rightarrow A$ Farewell to Maria, and The World of Stone as well as Curzio Malaparte.

In the case of Lahola, this is not exclusively "concentration camp literature"; its scope is broader. The internal symmetry used in the construction of stories is remark- 
able. Many times Lahola copies the five-member structure of the construction of a dramatic text, beginning with an exposition and ending with a disaster. Within the heart of Lahola's stories, there are dramatic situations at the plot level with implicit elements of distancing. They refer to an environment and mentality that the reader cannot know from his or her own experience. Also, there are points in the narrative that are remarkable and reminiscent of drama. The conclusions of the amendments are typically sharp or semantically open. They are "overlapped" with the use of paradox, nonsense, extreme examples or black humour. The stories only have a general sense of timing, and the setting is only roughly and generally defined: "Once a hundred thousand years ago, during the ice age or immediately after the world began to melt from below, this mountain valley had to be engraved by a glacial body like a large scaly reptile when dragging his tail behind him" (Lahola, 1994, p. 111). The stories thus become parables and allegories on the subject of endangered humanity. Lahola's interpreter Jozef Felix wrote about the prose: "If Lahola's characters feel anxious, they get it from the basic feeling of a dehumanised world [...]. In all his characters we find anxiety, but it is the anxiety of the author who loves mankind and life above everything else and who, through the images of the dehumanised world, wants to humanise mankind and the world, and to warn of the 'abyss' into which mankind has entered." (Felix, 1994, p. 303)

\section{Main Topics and Problems}

In Lahola's prose, the reader will find references to the impossibility of immediately naming the events which are happening. The language assumes the function of the medium used for the purpose. The "abyss" into which the reader and the author descend is also the abyss of language and the possible naming of the complicated events. In the midst of these events, the victim and the witness are the same person. The language is also related to expressing the search how to call the event of death, which is deprived of all the traditional deposits of culture. The fact of extinction here is represented by the term liquidation, which lacks the context of adequate naming. The author thus addresses readers from the unknown world to a completely different experience, "in a special way of talking”, as the protagonist of Lahola's play Inferno comments. There is a gap between the theme, accompanied by high moral expectations, and its "low" (protocol, elementary) aesthetically not stylised transcription. In the short stories, the source of the authentic possibility of being very close to the event; the language seemed not to be spoken for us, but spoken directly within us. The theme of the body and corporeality is a frequent accompanying motif for presentation the event of liquidation. The thematisation of the body at risk, the stories of violence, destruction and death provoke a reflection on the relationship between body and soul in Lahola's prose. This is exemplified in the short stories About Body and Soul, Twenty-Five Lashes of a Cane, Accidental Acquaintance (Náhodná známost') and The Last Thing. In the last story, the dead body is a prop of the plot, a source of the plot for telling the truth about the limits of mankind's humanism. The extraordinarily large, 
frozen corpse of a comrade is a source of conflict between two men who want to "save" it from ritual dishonour by the enemy. Also the religious duty to bury dead body in Judaism can play a role. The idea is to smash the hard-frozen corpse into pieces, or to preserve its integrity, symbolically also understood as being the last chance to preserve the integrity of a world broken into pieces. In the spirit of Lahola's desire for absurdity and nonsense, the first alternative prevails, the corpse is smashed up, and the scene closes with an epilogue that comments on the absurd decision. "Melius brought his half of Joc to the other half that lay near his bearded comrade. He lay on the frozen ground, leaned up on his elbow, waiting for what was going to happen next. It was impossible for him to go with one half or the other. Bearded as the devil was, he was right, he thought. Half a person is not a human, even if he is lying there in pieces or whatever" (Lahola, 1994, p. 134).

\section{Cited Works}

Felix, J. ( 1968). Nad novelami Leopolda Laholu. In: L. Lahola, Posledná vec. Bratislava: Slovenský spisovatel', 1968, pp. 301-312. Lahola, L. (1994). Posledná vec. Bratislava: F.R\&G.

\section{Further References}

Domorák, D. (2019) Existenciálna poetika - Leopold Lahola (Vtáčí spev). Slovenská literatúra, 66(2), pp. 114-128. Hamada, M. (1993). Nad prozaickou tvorbou Leopolda Laholu. Slovenské pohl’ady, 109(3), pp. 32-34. Paštéková, J. (2007). Kádrový profil životnej energie. In: L. Lahola, Posledná vec a iné. Bratislava: Kalligram, pp. 567-583. Prušková, Z. (1996). Vyslovitelnost’ nevyslovit’elného alebo štrnást’ noviel Leopolda Laholu. Česká literatura, 44(3), pp. 309-318. Špitzer, J, (1994). Exil v exile. In: L. Lahola, Posledná vec. Bratislava: F.R.\& G. pp. 5-22. Vodičková, M. (1969). Doslov. In: L. Lahola, Poslední věc. Praha: Naše vojsko, pp. 249-252. 